\title{
The Current State of Characterization of Romanian Vitis vinifera L. Germplasm by Molecular Markers
}

\author{
Monica HÂRȚA ${ }^{1 *}$, Doru PAMFIL ${ }^{1)}$ \\ 1) Faculty of Horticulture, University of Agriculture Sciences and Veterinary Medicine, 400372, Cluj- \\ Napoca, 3-5, Mănăştur Street, Romania \\ ${ }^{*}$ Corresponding author, e-mail: monica_bodea@hotmail.com
}

Bulletin UASVM Horticulture 71(2) / 2014

Print ISSN 1843-5254, Electronic ISSN 1843-5394

DOI:10.15835/buasvmcn-hort:10751

\begin{abstract}
In recent years, the concerns of some research teams have focused in development an international strategy for the germplasm collections characterization of important horticultural species, as response to the European Union initiative for inventory and conservation of genetic resources. In this context, the European Union has developed international research projects having as main aim collecting the data and improving knowledge regarding conservation and sustainable use of Vitis genetic resources in Europe. Romania has a multimillenary tradition in grapevine cultivation and wine production. Considering this, it is necessary to use efficient and reliable methods for the accurate identification of autochthonous and newly created grapevine cultivars included in national germplasm collections. The intensive renewals of grapevine plantations, implementation of EU regulations and reshaping of the national viticulture and wine industries, that take place at present in Romania, require application of modern methods for the accurate identification of valuable cultivars. In this paper, the advantages of using DNA markers in identification and characterisation of grape varieties included in Romanian germplasm collections were discussed. The aim of this review was to highlight the importance of molecular markers usage in the studies related the genetic diversity characterisation of this important species.
\end{abstract}

Keywords: Vitis, DNA, markers, ampelography, genetic resources

\begin{abstract}
Abbreviations: deoxyribonucleic acid (DNA), Polymerase Chain Reaction (PCR), Random Amplified Polimorphic DNA(RAPD), Sequence Characterized Amplified Region (SCAR), Simple Sequence Repeats (SSR), chloroplastic Simple Sequence Repeats (cpSSR), Unweighted Pair Group Method with Arithmetic Mean (UPGMA)
\end{abstract}

\section{INTRODUCTION}

Characterization of grapevine varieties has been a concern since antiquity (Theophrastus, c.371-287 BC). Over the centuries, the methodology used to describe varieties was permanently improved due to the accumulation of new knowledge and the progress registered in related fields of viticulture (Levadoux, 1956; Viala and Péchoutre, 1910; Zahary and Hopf, 2000).

The traditional methods for the identification and differentiation of cultivars based on ampelography and ampelometry are not very accurate due to the influence of the external factors.
The phenotype of varieties are influenced by environmental conditions as well as phytosanitary and nutritional state. The morphological features studied in ampelographic description can be influenced by different environments and identification of infected or otherwise off-type plants is susceptible to mistakes (Sefc et al., 2001).

Application of ampelographic methods for varieties characterisation requires skilled personnel, usually without access and knowledge of the thousands of different cultivars in use worldwide, because there is no collection that contains the huge volume of genetic resources (the total number of grapevine cultivars from ampelographic collections is estimated to be more than 15000).Ampelography experts usually know grapevine cultivars in use in their region and are not familiar with those from other regions. Additionally, reproducibility and standardisation between distant ampelography observations has proved difficult to achieve (Sefc et al., 2001). 
For these reasons, diverse techniques for molecular characterisation have been developed and applied to cultivar differentiation in grapevines.

Isoenzyme analysis of grapevine cultivars has been assessed by Benin etal. (1988), Eiras-Dias and Bruno-Sousa (1998), Parfitt and Arulsekar (1989), Sanchez-Eschibano et al. (1998). This technique presents some drawbacks: the expression of enzyme may depend on the developmental stage of the plant or on environmental conditions and the fresh plant material with identical developmental stages is absolutely necessary for each of the analyzed samples (Walter et al., 1989).

The analysis at the DNA level was the next step in the development of molecular markers. DNA based techniques are more valuable tools for grapevine characterisation(Ye et al., 1998). DNA markers are directly influenced by genotype but are independent of phenotype and environmental factors ( Grando and Frisinghelli, 1998).

PCR molecular marker techniques such as RAPD (Random Amplified Polimorphic DNA) have been preferred by some research groups for grape genome studies (Collins and Symons, 1993; Grando et al., 1995; Luo and He, 2001; Karataș and Agaoglu, 2010; Moreno et al., 1995).

RAPD analysis is an easy, cheap and fast method for the identification of genetic differences between grape cultivars at molecular level with satisfying levels of detected polymorphism. The major disadvantage of this PCR-based method is the dependence of the results on experimental conditions. Standardisation of RAPD protocol and comparison of the results between laboratories is quite difficult (This et al.,1997).

Some research groups (Hong and Bakalinsky, 1996; Korpas et al., 2009; Zhijianet al., 2010) converted the polymorphic RAPD markers to SCAR (Sequence Characterized Amplified Region) markers with specific PCR primers. These type of markers are useful especially in genome mapping when they can be associated with a phenotype, for example in the case of the seedlessness trait (Lahogueet al., 1998; This et al., 2000).

Delseny et al. (1983) demonstrated the existence of repeated simple sequence motifs in plant nuclear DNA. Simple sequence (also called microsatellite) repeats were detected in plant and organelle genomes (Lagercrantzet al., 1993; Wang et al., 1994) and these sequences represented a major source of genetic variation suitablefor plant genetics (Morgante and Olivieri, 1993).

Thomas et al. (1993) showed for the first time that repetitive DNA sequences were abundant in grapevine and very informative for identifying $V$. vinifera cultivars. The studies on pedigree analysis demonstrated that the microsatellite alleles were inherited in a co-dominant Mendelian manner (Thomas and Scott, 1993) and were suitable for genetic mapping and investigation of genetic relatedness (Thomas et al., 1994).

The interest in evaluating genetic relatedness within the Vitis genus, the high level of genetic diversity in grapevine and the requirement for a unitary system of variety recognition (useful for certifying the identity of grape cultivars) require integration and exploitaiton of the genotype data which are revealed by microsatellite loci in Vitis genus (Grando and Frisinghelli, 1998). Reproducibility and standardisation of microsatellite profiling is usually easy to achieve, which thus facilitates transfer and comparison of data between distant laboratories (Sefc et al., 2000).

In this context, in some countries (Greece, Hungary, Croatia, Czech, Italy) the scientific informations obtained by molecular markers analysis were grouped into national grape databases with the main aim to assure the precise characterisation of grape varieties included in germplasm funds, while others (Germany, France, Italy) are partners in coordination the European Vitis Database (Hârța and Pamfil, 2013).

International collaboration must result in the near future into an international database of SSR profiles of cultivars from all collections worldwide, to support the management of ampelographic collections as well as a microsatellite-based certification system (Thomas et al., 1994).

\section{THE WINE GROWING SECTOR IN ROMANIA: PAST AND FUTURE}

Romania is one of the European viticultural countries with a multimillenary tradition in grapevine cultivation and wine production. Numerous archaeological discoveries attest the cultivation of grape on the Romanian territory even since the Neolithic, and the words: strugure (grape) and butuc (grape vine) are inherited from the Dacians. Herodot, Platon and Homer are just a few names of the antiquity that wrote about 
Thracians as being great cultivators of vine (Oprea and Moldovan, 2007).

In Romania many varieties of grapevine are the result of natural or empirical selection made by generations of growers who have obtained valuable Romanian varieties. Currently, an accurate inventory of the number of existing local varieties in the pre-phylloxera era is difficult to achieve since the occurrence of phylloxera (1884) resulted in the destruction of vineyards and therefore the disappearance of valuable local biotypes (Pușcă, 2010).

The disappearance also in the post-phylloxera era of some valuable native grapevine varieties was due to the influence of a complex of unfavourable factors such as: the chaotically introduction in some vineyards of imported varieties from worldwide without their adequate zoning, grafting using as scion varieties with uncertain or unknown origin, the lack of a coherent and effective strategy in reconstituting the vineyards a priori without grafting the autochthonous valuable biotypes on American rootstocks, the prejudices about the quality and production quantity of local varieties compared to imported varieties highlighted internationally as valuable. For example, before the "Phylloxera Crisis" four autochthonous grapevine varieties ("Crâmpoşie", "Braghina", "Gordin" and "Tămâioasă Românească") were cultivated in the vineyard Drăgășani and after 3-4 decades of the emergence of this pest, which fully decimated some vineyards, over 200 foreign varieties were cultivated (Pușcă, 2010).

At present, the Romanian wine growing area is divided into eight wine growing zones and the development strategy to promote indigenous varieties sector constitutes a main goal, as a safe way to make a favourable lobby for wine sales on international markets (Popa, 2009).

\section{STATUS OF THE ROMANIAN GRAPEVINE GERMPLASM}

Grapevine genetic resources are maintained in Romania in ampelographic collections located especially in research institutes and stations for Viticulture and Enology (ValeaCălugărească, Iași, Bujoru, Odobești, Murfatlar, Pietroasa, Drăgășani, Blaj, Miniș, Ștefănești) and also in the agronomic universities (collections included usually into Viticulture departments). Botanical gardens from some Romanian locations (București, Cluj-Napoca,
Jibou, Iași), small private collections and wine grower schools also include and conserve different type of grapevine genetic resources.

Serdinescu (2013) stat that Romanian grapevine germplasm contain different types of genetic resources, respectively: eight wild species (Vitiscandicans, V. champinii, V. longii,V. manticola, $V$. riparia, $V$. rubra, $V$. rupestris and $V$. solonis), rootstocks, European, Asian and North American varieties for table and wine grapes (about 1400 cultivars), directly produced hybrids (42 cultivars) and interspecific hybrids (85 cultivars). The cultivars introduced in the ampelographic collections are originatedfrom 19 European countries, 9 states from Asia and 2 countries from North America.

It is important to note that grapevine germplasm collections include local and newly createdvarieties (181 cultivars and 98 clones) resulting from natural selection or breeding activity of the species V.vinifera.

\section{GENETIC STUDIES OF THE ROMANIAN VITIS VINIFERA GERMPLASM}

In the past, in Romania as in other countries, vine cultivars were identified by traditionally skills based on ampelography classification.

Under these conditions, the expression of many morphological analyzed traits were often affected by developmental stages of plants and environmental factors. The morphological variability and the subjective evaluation caused errors of identification and characterisation of some Romanian grapevine cultivars.

In this regard, the studies concerning genetic diversity are important not only for elucidation of the grapevine varietal origin , but also for breeding and conservation strategies of this species.

\section{RAPD markers}

Random Amplified Polymorphic DNA (RAPD) is the simplest and cheap PCR based method and was use like a valuable tool to analyse the genetic fidelity of in vitro propagated plants.

Pop et al. (2005) used RAPD analysis to reveal the molecular polymorphism of some grape varieties: "Fetească albă", "Fetească regală", "Riesling Italian", "Traminer", "Cabernet Sauvignon", "Muscat Ottonel", "Merlot", "Cetăţuia", "Napoca" and "Timpuriu de Cluj" cultivated in some vineyards of Romania. Genetic DNA was extracted 
from leaves using a modified version (Pop et al., 2003) of the protocol published by Lodhi et al. (1994). Nine of the 20 primers tested revealed polymorphism between varieties and the built RAPDistance 1.04 software dendrogram grouped the analyzed cultivars in two main branches.

Assessment of genetic stability and fidelity of some micropropagated Vitis vinifera autochthonous "Fetească neagră" clones have been studied by ampelometric and RAPD markers. Gheorghe et al. (2009) reported that all regenerated plants and studied by RAPD analysis did not showed any nuclear DNA polymorphism. The results proved that these dominant molecular markers can be used to gain rapid and precise information about genetic similarities or dissimilarities in micropropagation systems.

To estimate genetic relationships among 36 local vine cultivars, RAPD analysis was performed (Bodea et al., 2009) with 24 decamer primers selected from a total of 40 primers. These primers generated polymorphic bands among the studied genotypes. UPGMA dendrogram was constructed based on genetic distances using the program Tree View. The analyzed genotypes clustered into three main groups and the values of genetic distances between cultivars showed differences with satisfying level of detect polymorphic and rare DNA bands.

Butiuc-Keul et al., 2011 performed a study regarding molecular characterization of in vitro plantlets from three cultivars: "Muscat Ottonel", "Fetească regală" and "Italian Riesling" by cpSSR markers and the results showed the three distinct haplotypes. Specific cpSSR markers have been identified for the first time for "Fetească regală" cv. The in vitro plantlets were analyzed by mean of RAPD markers in order to identify the somaclonal variations. The RAPD markers could not identify somaclonal variations, thus in vitro multiplication of these three cultivars seems to be a clonal propagation.

Gheorghe et al. (2008) made a study to establish the genetic relationships among 11 local grapevine varieties ("Timpuriu de Cluj", "Napoca", "Transilvania”, "Cetăţuia”, "Splendid", "Blasius", "Selena", "Amurg", "Brumăriu”, "Astra" and "Radameș") grown in two different regions in Romania by using RAPD markers. A general characteristic for all obtained RAPD patterns with DNA amplicons was the high degree of variation among cultivars revealed by proportion of polymorphic bands ranging from $78 \%$ to $100 \%$. The data obtained in this study provided valuable genetic information, important to reveal the uniqueness of some Romanian grapevine varieties and their high degree of polymorphism detected by RAPD markers. The high level of genetic variation among tested varieties may be due to differences between cultivars with different geographical origine, the significant inter-population distances and also the winegrowing tradition.

\section{SSR markers}

The PCR based microsatellite analysis has been applied to identify and discriminate 11 native Romanian grapevine varieties with the goal to obtain a genotype profile by using microsatellites, the undisputed markers of choise for grape identification and parentage analysis (Gheorghe et al., 2010). According to these results, each of the investigated cultivars constitutes an independent source of genetic variation, and a valuable resource of genetic traits for grapevine breeding programs.

Motoc et al. (2010) conducted a study of genetic variability revealed by sequencing analysis at two microsatellitic loci, in some grapevine cultivars from Romania and Republic of Moldavia. The results obtained by sequencing the amplicons from two SSR loci (VVMD 7 and VVMD 17) explained the allelic variability observed by genotyping, both in Romanian and Moldavian analyzed cultivars.

Microsatellite loci represent the molecular markers of choice for assessing genetic identities and phylogenetic relationships between different grapevine varieties and gene pools. Genetic profiles of nine grapevine cultivars (four of them non autochthonous: "Muscat Ottonel", "Italian Riesling", "Cabernet sauvignon", "Sauvignon blanc" and five of Romanian origin -"Tămâioasă românească", "Negru aromat", "Fetească albă", "Fetească regală" and "Fetească neagră") from ampelographic collection of National Institute for Biotechnologies in Horticulture Ştefăneşti -Arges was carried out, based on 15 microsatellite markers (Gheţea et al., 2010). The results revealed the existence of some genetic particularities, for example conserved allelic variants, alleles significantly different (in base pairs number) from those already were identified in other gene pools as the consequence of the action of some local 
evolution mechanisms, making the Romanian Vitis vinifera gene pool as valuable as others genetic resources in the world.

Six nuclear SSR loci (SS2, MD5, MD7, MD27, ZAG 62 and ZAG 79) were used to characterize four autochthonous grapevine cultivars ("Băbească neagră”, “Fetească regalǎ”, “Frâncuşa”, and “Grasa de Cotnari"), including four international comparative genotypes ("Cabernet sauvignon", "Chardonnay blanc", "Riesling Italian" and "Merlot") by Hârța and Pamfil (2013). The DNA microsatellite analysis was used to construct a barcode system, a visual representation of the number and size of alleles, allowing easy detection of genotypic differences between analyzed cultivars. The results showed that this system of data grouping can be useful for characterisation of Romanian cultivars at DNA level. The integration of such DNA barcodes into nationally and internationally coordinated databases could increase the accuracy for grapevine genetic resources management in Romania.

Coste et al., (2010) analyzed twenty two grapevine cultivars (8 international and 14 autochthonous varieties) whith six microsatellite loci (VVMD5, VVMD7, VVMD27, VVS2, VrZAG62, VrZAG79) in order to characterize their genetic diversity and to establish the maintenance of their identity and purity throughout two different national germplasm collections and one private collection from Romania. The results have led to the conclusion that genetic characterization of grapevine cultivars can certify their authenticity and purity, two features that are of prime importance, especially in relation to quality control and consumer information. The genetic profiles for some analyzed varieties were compared and proved to be consistent with those existing in the European Vitis Database.

Accurate identification of the grapevine cultivars is important for Romanian winemakers and the extrapolation of the methods for identifying grapevine varieties into musts and wine is relevant in controlling the quality and authenticity of aromatic and high quality wines. Hârța et al. (2010) realised a molecular SSR (Simple Sequence Repeats) analysis using some Vitis vinifera L. varieties ("Busuioacă de Bohotin", "Tămâioasă românească", "Negru aromat", "Fetească neagră", "Negru de Drăgăşani", "Amurg" and "Novac") in order to detect the grapevine cultivars present in monovarietal musts. DNA provided from each analyzed cultivar was successfuly extracted from leaves and must at the beginning of the fermentation (day 1) using CTAB method and the size of amplicons generated with eight SSR primers (VVS2, VVS5, VVS29, MD5, MD7, ZAG 47, ZAG 62, ZAG 79) were automaticaly computed. Results showed that there were no differences between the corresponding leaf and varietal must profiles and SSR markers were successfuly used for identification of grapevine cultivars in monovarietal musts.

The main goal of the study realised by Hârța et al., 2011 was the isolation of DNA both from experimental and commercial wines to differentiate some Romanian grapevine cultivars ("Tămâioasă românescă", "Galbenă de Odobești", "Fetească neagră" and "Busuioacă de Bohotin") by PCR using experimental wines as samples. Residual DNA quality and specificity were verified using PCR amplification with co-dominant simple sequence repeat (SSR) markers (VVS2, VVMD27, VVMD5 and VVMD7). The results obtained in this research revealed that even 18 months after wine fermentation was detected residual DNA suitable for DNA fingerprinting. Among the microsatellite loci tested, VVS2 marker, which generated the shortest PCR amplicons (119-138 bp), amplified all wines samples. Authentication of the grape varieties in samples provided by comercial wines based on PCR methodology was unsuccessfully due to insufficient amount of residual DNA.

\section{CONCLUSIONS AND PROSPECTS FOR THE FUTURE}

Although Romania has a rich vine germplasm fund, the efforts of some national research teams to characterize grape varieties at DNA level are still under-emphasized in comparison with some international research results in DNA ampelography.

Among the molecular markers, microsatellite loci have been prefered for the identification of cultivars or rootstock material, during propagation in nurseries as well as the certification of grape juice before vinification with the prospect that will almost certainly be routinely used by the wine industry.

Genetic diversity studies of autochthonous and newly created Vitis vinifera cultivars by molecular markers must continue in the 
future taking into consideration the invaluable importance of some national varieties collections and the knowledge on their genetic relationships as a basis for protection and efficient exploitation of European Vitis biodiversity. The maintenance of local varieties should be a primary objective in order to prevent genetic erosion in grapevine.

International collaboration with the main aim to continue the phenotypic and genetic characterization of the autochthonous Romanian grapevine germplasm will represent a major challenge for Vitis research groups because in Romania there are many valuable genetic resources that need to be studied and introduced into international databases.

\section{REFERENCES}

1. Benin M, Gasquez J, Mahfoudi A, Bessis R (1988). Caractérisationbiochimique des cépages de Vitis vinifera L. par électrophorèse $d$ > isoenzymesfoliaires: essai de classification des variétés. Vitis 27: 157-172.

2. Bodea M, Pamfil D, Pop R, Pop IF (2009). Use of Random amplified polymorphic DNA to study genetic diversity anong Romanian local vine (Vitis vinifera L.) cultivars. Bul. UASVM Horticulture. 66(1):17-22.

3. Botta R., Scott NS, Eynard, I, Thomas MR (1995) Evaluation of microsatellite sequence-tagged site markers for characterizing Vitis vinifera cultivars. Vitis 34(2): 99102.

4. Bowers JE, Dangl GS, Vignani R, Meredith CP (1996) Isolation and characterization of new polymorphic simple sequence repeat loci in grape (Vitis vinifera L.). Genome 39: 628-633.

5. Bowers J.E, Dangl GS, Meredith CP (1999b). Development and characterization of additional microsatellite DNA markers for grape. Am. J. Enol. Vitic. 50(3): 243-246.

6. Butiuc-Keul AL, Coste A, Crăciunaș C (2011). Molecular characterization and in vitro preservation of some grapevine cultivars. Rom. Biotech. Letters 16(3): 62266233.

7. Cipriani G, Frazza G, Peterlunger E, Testolin R (1994). Grapevine fingerprinting using microsatellite repeats. Vitis 33: 211-215.

8. Collins GG. and R.H. Symons (1993) Polymorphisms in grapevine DNA detected by the RAPD PCR technique. Plant Mol. Biol. Rep. 11: 105-112.

9. Coste A, Postolache D, Popescu F, Butiuc-Keul AL (2010). Authentification of valuable grapevine varieties from Romania through molecular markers. Rom. Biotech. Letters 15(1):3-11

10. Delseny M, Laroche M, Penon P (1983). Detection of sequences with Z-DNA form in potential in higher plants. Biochem. Bioph. Res. Commun. 116: 113-20.

11. Eiras-Dias JE, Bruno-Sousa R (1998). Isoenzymatic polymorphism differentiation of Portuguese grapevine cultivars. Am. J. Enol. Vitic. 49(1): 86-90.
12. Gheorghe RN, Visoiu E, Popescu CF, Pamfil D (2009). Assement of genetic stability and fidelity of some micropropagated Vitis vinifera L. "Feteasca neagra" clones by ampelometric and RAPD markers. Bull. UASVM Horticulture, 66(1):51-57.

13. Gheorghe RN, Popescu CF, Pamfil D, Ciocârlan CN, Sestraș RE (2010). Genetic diversity of some Romanian grapevine cultivars as revealed by microsatellite markers. Rom. Biotech. Letters Vol. 15sup(2):26-31.

14. Gheorghe RN, Popescu CF, Pamfil D, Pauchnecht AE (2008). Genetic diversity evaluation of some autochthonous grapevine varieties by RAPD markers.Lucr. Stiintif. Horticultura, Anul LI (51):73-76.

15. Ghețea LG, Motoc RM, Popescu CF, Bărbăcar N, Iancu D, Constantinescu C, Bărbării LE (2010). Genetic profiling of nine grapevine cultivars from Romania, based on SSR markers. Rom. Biotech. Letters Vol. 15sup(1):116-124.

16. Grano MS, Frisinghelli C (1998). Grape microsatellite markers: sizing of DNA alleles and genotype analysis of some grapevine cultivars. Vitis (37)2: 79-82.

17. Grando MS, De Michelli L , Biasetto L, Scienza A (1995): RAPD markers in wild and cultivated Vitisvinifera. Vitis 34: 37-39.

18. Hârța M, Pamfil D, Pop R, Pop IF (2010). Identification of Romanian Vitis vinifera L. cultivars in must using nuclear microsatellite markers, Bul. UASVM Horticulture, 67(1): 198-203.

19. Hârța M, Pamfil D, Pop R, Vicaș S(2011). DNA fingerprinting used to characterise some Romanian wine varieties, Bulletin UASVM Horticulture, 68(1): 143-148.

20. Hârța M, Pamfil D (2013). Molecular characterisation of Romanian grapevine cultivars using nuclear microsatellite markers. Bulletin UASVM Horticulture, 70(1): 131-136.

21. Hong X, Bakalinsky AT (1996). Identification of grape (Vitis) rootstocks using sequence characterized amplified region DNA markers. Hortscience 31(2):267-268.

22. Karataș H, Agaoglu YS(2010). RAPD analysis of selected local Turkish grape cultivars (Vitisvinifera). Genetic. Mol. Res. 5:9(4):1980-1986.

23. Korpas A, Baranek M, Pidra M, Hradilik J (2009). Behaviour of two SCAR markers for seedlessness within Central European varieties of grapevine. Vitis 48 (1): 3342

24. Lagercrantz U, Ellengren H, Andersson L (1993). The abundance of various polymorphic microsatellite motifs differs between plant and vertebrates. Nucleic Acids Res. 21(5): 1111-1115.

25. Lahogue F, This P, Bouquet A (1998). Identification of a codominant SCAR marker linked to seedlessness character in grapevine. Theor. Appl. Genet. 97 (5-6): 950959.

26. Levadoux L (1956). Les populations sauvages et cultivees de Vitis vinifera L. Annales de l'Amélioration des Plantes (6): 59-117.

27. Lodhi MA, Guang- Ning ZF, Weeden NF, Reisch BI (1994). A simple and efficient method for DNA extraction from 
grapevine cultivars, Vitis species and Ampelopsis. Plant Mol. Bio. Rep. 12(1):6-13.

28. Luo $S$, He $P$ (2001). Discrimination of wild grape native to China by RAPD markers. Vitis 40(3), 163-168.

29. Milanesi C, Costantini L, Firmati M, Antonucci, F, Faleri C, Buracchi A, Cresti M (2014). Geometric Morphometry and Archaeobotany: Characterisation of Grape Seeds (Vitis vinifera L.) by Analysis of Form. Open Access Library Journal, 1: e634. http://dx.doi.org/10.4236/oalib.1100634

30. Moreno S, Gogorcena Y and Ortiz J M (1995): The use of RAPD markers for identification of cultivated grapevine (Vitisvinifera L.) ScientiaHorticulturae 62: 237-243.

31. Morgante M, Olivieri AM (1993). PCR-amplified microsatellites as markers in plant genetics. The Plant J. 3: 175-182.

32. Motoc RM, Ghețea LG, Popescu CF, Bărbăcar N, Savin G, Iancu D, Constantinescu C, Bărbării LE (2010). Genetic variability revealed by sequencing analysis at two microsatellitic loci, in some grapevine cultivars from Romania and Republic of Moldavia. Rom. Biotech. Letters Vol. 15sup(2):120-124.

33. OpreaŞ, Moldovan SD (2007). Ameliorareaviţei de vie înRomânia. EdituraPoliam, Cluj-Napoca, 269p.

34. Parfitt, DE, Arulsekar S (1989). Inheritance and isoenzyme diversity for GPI and PGM among grape cultivars. J. Am. Sci. Hort. Sci. 114: 486-491.

35. Popa D (2009). Romanian wine growing sector in the context of European integration, competitive and sustainable development. Bul. UASVM Horticulture, 66(1): 341-344.

36. Pop R, Ardelean M, Pamfil D, Gaboreanu IM (2003). The efficiency of different DNA isolation and purification protocols in ten cultivars of Vitis vinifera. Bul. UASVM, Horticulture, 59(1): 259-261.

37. Pop R, Ardelean M, Gaboreanu I.M, Pamfil D, Cordea M, Raica P, Bodea M, Cantor M (2005). RAPD analyses in revealing molecular polymorphism in grape varieties from wineyards of Romania, Proceedings of XL Croatian Symposium on Agriculture, 229-230.

38. Pușcă IM (2010). Vechi soiuri românești de viță de vie. $2^{\text {nd }}$ Edition. Rom. lang. Ed. Intact, 246p

39. Sánchez-Eschibano EM, Ortiz JM, Cenis JL (1998). Identification of table cultivars (Vitis vinifera L.) by the isoenzymes from the woody stems. Gen. Res. And Crop Ev. (45): 173-179.

40. Sefc, K.M., Lopes MS, Lefort F, Botta R, RoubelakisAngelakis KA, Ibanez J, Pejic I, Wagner HW, GlösslJ, SteinkellnerH (2000). Microsatellite variability in grapevine cultivars from different European regions and evaluation of assignment testing to assess the geographic origin of cultivars. Theor. Appl. Genet. 100:498-505.

41. Sefc K M, Lefort F, Grando M S, Scott K D, Steinkellner H, Thomas M R (2001). Microsatellite markers for grapevine: A state of the art. Molecular Biology \& Biotechnology of Grapevine, Edited by K.A. Roubelakis-Angelakis, Kluwer Ac. Pub., The Netherlands.

42. Serdinescu A (2013). Grapevine germplasm in Romania. Report of WGs1 and 2 Join meeting-COST action FA1003, Bucharest.

43. Theophrastus (1916). Theophrastus: Enquiry into Plants. Hort AF (transl.) ed. Loeb Classical Library.New York.

44. This P, Cuisset C, Boursiquot JM (1997). Development of stable RAPD markers for the identification of grapevine rootstocks and the analysis of genetic relationships. Am. J. Enol. Vitic. 48: 492-501.

45. This P, Lahogue F, Adam-Blondon AF, Doligez A, Bouquet A (2000). Towards marker-assisted selection for seedlessness in grapevine. Acta Hort. 528(1): 221-229.

46. Thomas MR, Matsumoto S, Cain P, Scott NS (1993). Repetitive DNA of grapevine: classes present and sequences suitable for cultivar identification. Theor. Appl. Genet. 86: 173-180.

47. Thomas MR, Scott NS (1994). Microsatellite sequence tagged site markers: simplified technique for rapidly obtaining flanking sequences. Plant Mol. Biol. 12: 58-64.

48. Thomas MR, Scott NS (1993). Microsatellite repeats in grapevine reveal DNA polymorphisms when analysed as sequence-tagged sites (STSs). Theor. Appl. Genet. 86: 985990.

49. Ye, GN, Soylemezoglu G., Weeden NF, Lamboy WF, Pool RM, Reisch BI (1998). Analysis of the relationship between grapevine cultivars, sports and clones via DNA fingerprinting. Vitis 37: 33-38.

50. Viala P, Péchoutre F (1910). Origines de la vigne in Viala and vermorel. Traité génerale de Viticulture, ampélographie (1): 497-504.

51. Zahary D, Hopf M (2000). Domestication of plants in the

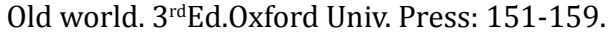

52. Zhijian T, Li SA, Dhekney D, Gray J (2010). Molecular characterization of a SCAR marker purportedly linked to seedlessness in grapevine (Vitis). Mol. Breeding 25:637644

53. Walter, TW, Posluszny U, Kevan PG (1989). Isoenzyme analysis of the grape (Vitis). I. A practical solution. Can. J. Bot. 67: 2894-2899.

54. Wang Z, Weber JL, Zhong G, Tanksley SD (1994). Survey of plant short tandem repeats. Theor. Appl. Genet. 88: 1-6. 